\title{
Microzooplankton distribution in the Amundsen Sea Polynya (Antarctica) during an
}

\section{extensive Phaeocystis antarctica bloom}

Rasmus Swalethorp ${ }^{* 1,2,3}$, Julie Dinasquet ${ }^{* 1,4,5}$, Ramiro Logares ${ }^{6}$, Stefan Bertilsson ${ }^{7}$, Sanne Kjellerup ${ }^{2,3}$, Anders K. Krabberød ${ }^{8}$, Per-Olav Moksnes ${ }^{3}$, Torkel G. Nielsen², and Lasse Riemann ${ }^{4}$

${ }^{1}$ Scripps Institution of Oceanography, University of California San Diego, USA

${ }^{2}$ National Institute of Aquatic Resources (DTU Aqua), Technical University of Denmark, Denmark

${ }^{3}$ Department of Marine Sciences, University of Gothenburg, Sweden

${ }^{4}$ Marine Biological Section, Department of Biology, University of Copenhagen, Denmark

${ }^{5}$ Department of Natural Sciences, Linnaeus University, Sweden

${ }^{6}$ Institute of Marine Sciences (ICM), CSIC, Spain

${ }^{7}$ Department of Ecology and Genetics: Limnology and Science for Life Laboratory, Uppsala University, Sweden

${ }^{8}$ Department of Biosciences, Section for Genetics and Evolutionary Biology (Evogene), University of Oslo, Norway

*Equal contribution, correspondence: rswalethorp@ucsd.edu, jdinasquet@ucsd.edu

Key words: ciliate; dinoflagellate; growth rates; Southern Ocean; Antarctica; Amundsen Sea polynya; Gymnodinium spp. 
bioRxiv preprint doi: https://doi.org/10.1101/271635; this version posted February 26, 2018. The copyright holder for this preprint (which was not certified by peer review) is the author/funder, who has granted bioRxiv a license to display the preprint in perpetuity. It is made available under aCC-BY-NC-ND 4.0 International license.

Abbreviations: ASP: Amundsen Sea Polynya; SO: Southern Ocean; HNF: Heterotrophic nanoflagellates; OTU: Operational Taxonomic Unit, DFM: Deep Fluorescence Maximum 


\section{$1 \quad$ Abstract}

2 In Antarctica, summer is a time of extreme environmental shifts resulting in large coastal

3 phytoplankton blooms fueling the food web. Despite the importance of the microbial loop in

4 remineralizing biomass from primary production, studies of how microzooplankton communities

5 respond to such blooms in the Southern Ocean are rather scarce. Microzooplankton (ciliates and

6 dinoflagellates) communities were investigated combining microscopy and 18S rRNA sequencing

7 analyses in the Amundsen Sea Polynya during an extensive summer bloom of Phaeocystis antarctica.

8 The succession of microzooplankton was further assessed during a 15-day induced bloom microcosm

9 experiment. Dinoflagellates accounted for up to 58\% the microzooplankton biomass in situ with

10 Gymnodinium spp., Protoperidium spp. and Gyrodinium spp. constituting 87\% of the dinoflagellate

11 biomass. Strombilidium spp., Strombidium spp. and tintinids represented $90 \%$ of the ciliates biomass.

12 Gymnodinium, Gyrodinium and tintinnids are known grazers of Phaeocystis, suggesting that this

prymnesiophyte selected for the key microzooplankton taxa. Availability of other potential prey, such

as diatoms, heterotrophic nanoflagellates and bacteria, also correlated to changes in microzooplankton community structure. Overall, both heterotrophy and mixotrophy appeared to be key trophic strategies of the dominant microzooplankton observed, suggesting that they influence carbon flow in the microbial food web through top-down control on the phytoplankton community. 


\section{Introduction}

The Southern Ocean (SO) plays a central role in global biogeochemical cycles due to strong summer pulses of primary production (Sarmiento et al., 2004). Coastal polynyas contribute strongly to the efficiency of the biological pump through massive export of organic material (DiTullio et al., 2000) and formation of deep water masses (Williams et al., 2007). The summers, with elevated irradiance, reduced ice cover and subsequent input of nutrients, sparks a short but massive burst of phytoplankton in these areas (Smith Jr \& Gordon, 1997; Arrigo et al., 2012). To understand and predict the extent of $\mathrm{CO}_{2}$ sequestration in the $\mathrm{SO}$ (Sabine et al., 2004; Arrigo et al., 2008) it is therefore important to determine the fate of the extensive phytoplankton blooms occurring in the Antarctic polynyas.

Microzooplankton have been estimated to graze over half of the daily global planktonic primary production (Calbet \& Landry, 2004; Schmoker et al., 2013) and may thus exert significant top-down control on phytoplankton blooms in the SO (Bjørnsen \& Kuparinen, 1991; Kuparinen \& Bjornsen, 1992). Despite the key ecological functions of microzooplankton in the carbon cycle as either primary producers or as a trophic link between the microbial loop and higher trophic levels (reviewed in Sherr \& Sherr, 2009), they have received little attention in the productive polynyas of the SO. The Amundsen Sea Polynya (ASP) is one of the most productive polynya of the SO, characterized by dramatic perennial blooms (Arrigo \& van Dijken, 2003). In summer 2010-2011 the Amundsen Sea Polynya Research Expedition (ASPIRE) aimed to determine the fate of the high algal productivity. At the time of sampling, the ASP was undergoing an extraordinary bloom event dominated by the prymnesiophyte algae Phaeocystis antarctica (Alderkamp et al., 2015; Yager et al., 2016). 
Microzooplankton grazing pressure on Phaeocystis depends on whether the prymnesiophyte

occurs in its single cell or colonial form (Caron et al., 2000; Grattepanche et al., 2010; Grattepanche et al., 2011). Thus, the succession of the bloom affects the microzooplankton community, its grazing pressure (Verity, 2000), and impact on the biological pump. In the ASP, carbon export was high (up to $62 \%$ of net primary production - NPP) and grazing rates were low (32.5\% of the NPP in the upper 100 m of the water column (Yager et al., 2016)) compared to other regions of the SO (Froneman \& Perissinoto, 1996; Landry et al., 2002; Pearce et al., 2008; Schmoker et al., 2013). Nevertheless, microzooplankton grazing pressure on the NPP was far more important than that of mesozooplankton (Wilson et al., 2015; Yager et al., 2016) and became increasingly important later during the bloom (Lee et al., 2013; Yang et al., 2016). This underlines the importance of understanding the coupling between the microzooplankton community and these extraordinary blooms to better predict the fate of the carbon. This is pertinent as the Amundsen Sea ice-sheet and sea ice are rapidly melting due to environmental warming (Pritchard et al., 2009; Stammerjohn et al., 2015), which may modify the magnitude as well as the temporal and spatial dynamics of $P$. antarctica and diatoms blooms (Alderkamp et al., 2012).

In the present study, we examined the composition of the microzooplankton community in the ASP during an intense $P$. antarctica bloom. To improve taxonomic resolution we combined microscopy and 18S rRNA sequencing to characterize the community. Additionally, the microzooplankton succession during an intense bloom event was investigated through a 15-day induced P. antarctica bloom microcosm experiment. The aim was to improve our understanding of the environmental drivers shaping the community of these principal phytoplankton grazers within Antarctic polynyas during the productive Austral summer. 


\section{Materials and Methods}

\subsection{In situ conditions}

The sampling was conducted during the ASPIRE cruise in November 2010 to January 2011

onboard RVIB N.B. Palmer (cruise NBP1005; (Yager et al., 2012; Yager et al., 2016). Fourteen

stations were sampled for microzooplankton analyses via microscopy and 18S rRNA amplicon

sequencing (Fig. 1). Water was collected with 121 Niskin bottles mounted on a CTD rosette (Sea-Bird 911+). Detailed information on methods and in situ environmental parameters measured

(phytoplankton pigments, nutrients, bacteria and heterotrophic nanoflagellates - HNF abundance) can be found in Yager et al. (2016).

\subsection{Microzooplankton community and biomass}

Microscopy samples were collected at 10 of the 14 microzooplankton sampling stations (Fig. 1) traversing the ASP from the surface (2 - $5 \mathrm{~m}$ ), depth of fluorescence max. (DFM, $10-40 \mathrm{~m}$ ), and below the fluorescence peak $(50-180 \mathrm{~m})$. Water from the Niskin bottles was gently siphoned through silicon tubes into $300 \mathrm{ml}$ amber colored glass bottles and fixed in acidic Lugol's solution (2\% final

concentration). Bottles were stored cool and dark (max. 12 months) until appropriate sized sub-samples (depending on cell concentration) were transferred into sedimentation chambers, allowed to settle for 24 hours and microplankton identified and counted under microscope at the Latvian Institute of Aquatic Ecology. Cell volumes were calculated using appropriate geometric shapes following (Olenina, 2006). To correct for shrinkage due to Lugol preservation, cell volumes were adjusted by a 
81

82

factor of 1.33 (Stoecker et al., 1994). Biomasses of dinoflagellates, loricate and aloricate ciliates were calculated using carbon conversion factors by Menden-Deuer and Lessard (2000).

\subsection{RNA extraction, sequencing and taxonomic identification}

Between 1-6 liters of seawater were pre-filtered through a $20 \mu \mathrm{m}$ sieve and then sequentially filtered through 3 polycarbonate filters. Filters were flash-frozen and stored at $-80^{\circ} \mathrm{C}$. RNA was extracted using the NucleoSpin ${ }^{\circledR}$ RNA L kit (Macherey-Nagel) and quantified using a Nanodrop ND1000 Spectrophotometer. To remove DNA from RNA extracts, we used the TurboDNA kit (Ambion). RNA were reverse transcribed using the RT Superscript III random primers kit (Invitrogen) and hypervariable V4 region was amplified using the universal primers TAReuk454FWD1 (5'-

CCAGCASCYGCGGTAATTCC-3') and TAReukREV3 (5'-ACTTTCGTTCTTGATYRA-3') (Stoeck et al., 2010). Triplicate amplicon reactions were pooled and purified using NucleoSpin ${ }^{\circledR}$ Extract II (Macherey-Nagel). Purified amplicons were quantified with Picogreen Invitrogen) and pooled in equimolar concentration. Amplicon sequencing was carried out on a 454 GS FLX Titanium system (454 Life Sciences, USA) at Genoscope (http://www.genoscope.cns.fr/spip/, France).

All reads were were processed with Quantitative Insight Into Microbial Ecology pipeline, QIIME v1.4 (Caporaso et al., 2010). Only reads between $200-500$ bp were used. Reads were quality controlled and denoised using DeNoiser v 0.851 (Reeder \& Knight, 2010) implemented in QIIME. Subsequently, reads were clustered into Operational Taxonomic Units (OTUs) using UCLUST v1.2.22 (Edgar, 2010) at $99 \%$ similarity. Chimeras were detected and removed using ChimeraSlayer with a reference database derived from PR2 (Guillou et al., 2013). Representative reads were assigned to taxonomy by BLASTing them against the databases SILVA v108 (Quast et al., 2013), the PR2. Sequences are 
102

publicly available at ENA (PRJEB23910). Only OTUs representing $>0.1 \%$ of the total relative abundance of ciliates and dinoflagellates were further studied. Maximum likelihood trees were computed with MEGA7 (Kumar et al., 2016).

\subsection{Induced bloom microcosm experiment set-up}

The succession of the ciliate and dinoflagellate community was followed during the course of a 15 day Phaeocystis bloom induced in St. 35 DFM water (12 m). Triplicates incubations in 121

collapsible plastic containers were carried out for both unfiltered water and $200 \mu \mathrm{m}$ filtrates. The water from the Niskin bottles was gently siphoned into a 601 bucket, and vitamins and nutrients $(15 \mu \mathrm{M}$ $\mathrm{NH}_{4} \mathrm{Cl}$ and $1 \mu \mathrm{M} \mathrm{Na}_{2} \mathrm{HPO}_{4}$ ) were added before carefully mixing the water for the triplicate aliquots.

The filtered treatment was done to ensure absence of metazoan predators of dinoflagellates and ciliates, by gentle reverse filtration through $200 \mu \mathrm{m}$ mesh size filters. The containers were incubated at in-situ light $\left(\mathrm{PAR}=2.04 \mu \mathrm{mol} \mathrm{m}^{-2} \mathrm{~s}^{-1}\right)$ and temperature $\left(0 \pm 0.5^{\circ} \mathrm{C}\right)$ for 15 days and mixed by gentle rotation of the containers every $8 \mathrm{~h}$. The light and temperature conditions were monitored regularly during the experiment. Samples for nutrients, chlorophyll $a(\operatorname{chl} a)$, microzooplankton biomass and species composition (analyzed following same procedure as for in situ samples) were collected at the start of the incubation and after $2,4,7,10,13$, and 15 days. HNF were also measured by flow cytometry according to Christaki et al. (2011), while bacteria were enumerated with the flow cytometry method described by Gasol and del Giorgio (2000) for bacteria. Samples for 18S rRNA based community analysis as well as, Phaeocystis and diatom abundances were collected at the start, day 7 and at the end of the experiment (pooled triplicates). In order to avoid disturbance from air bubbles during mixing, air was squeezed out of the collapsible container after every sampling. All containers and materials were acid washed prior to use. 
129 Growth rates were calculated for each time step using the equation:

$\mu=\frac{\ln \left(B_{t 0+1}\right)-\ln \left(B_{t 0}\right)}{B_{t 0+1}-B_{t 0}}$

where $\mathrm{B}$ is the concentration or biomass at sampling day $\mathrm{t}_{0}$ and at the following sampling day $\mathrm{t}_{0+1}$.

\subsection{Data analysis}

135 Microzooplankton species richness (Margalef D), diversity (Shannon-Wiener H') and evenness

136 (Pielou's J') were calculated using the equations:

$$
D=(S-1) / \ln (N)
$$

$$
H^{\prime}=\sum_{i=1}^{S} p i \cdot \ln (p i)
$$

$$
J^{\prime}=H^{\prime} / \ln (S)
$$


140 where $\mathrm{S}$ is the no. of species, $\mathrm{N}$ is the no. of individuals and $\mathrm{p} i$ is the proportion of the $i$ th species. Size

141 evenness was calculated using cell abundances within five biovolume size groups $(<2000,2000-10000$,

$\left.142 \quad 10000-50000,50000-250000,>250000 \mu \mathrm{m}^{3}\right)$.

Spearman rank correlation analysis between microzooplankton community indices and environmental parameters was carried out in Sigmaplot v. 12 (Systat Software, Inc.). Correlation between Bray-Curtis resemblance matrices of microzooplankton species biomass and Euclidian 146 distance resemblance matrices of environmental parameters was tested using the BEST analysis in 147 Primer v. 6.1.7 (Primer-E, Ltd). The BIOENV algorithm and Spearman rank correlation method was 148 used. A stepwise distance-based linear model permutation test (DistLM, McArdle \& Anderson, 2001) was also performed to identify environmental variables best predicting community variation. The stepwise routine was run employing 9,999 permutations and using the AICc (Akaike's information criterion with second order correction) selection criterion. Results were visualized with a distancebased redundancy analysis (dbRDA, Anderson et al., 2008). Analysis of similarities in community composition (ANOSIM) was carried out by pairwise testing between different depth strata. To identify the species contributing most to the similarity between samples, a SIMPER analysis (SIMilarity PERcentage, Clarke \& Warwick, 2001) was performed. Lastly, testing of similarities between microscopy and 18S rRNA Bray-Curtis resemblance matrices was done by RELATE analysis of Spearman rank correlations. All biomass and environmental data were log transformed while abundance data was fourth root transformed. Environmental data was normalized by subtracting means 159 and dividing by the standard deviation (z-scores). 


\section{Results}

\subsection{Hydrography and microzooplankton}

The upper part of the water column $(30-50 \mathrm{~m})$ was characterized by increasing temperatures with increasing latitude and proximity to the ice shelf (Fig. 2). Inversely, salinity increased with decreasing latitude and proximity to the sea ice surrounding the polynya. Two stations along transect 2 deviated from this pattern; St. 57.21 where the upper $\sim 100 \mathrm{~m}$ was mixed as it was located in the wake of a drifting iceberg (Randall-Goodwin et al., 2015; Dinasquet et al., 2017), and St. 35 characterized by high surface temperatures. Detailed information on the hydrography is presented elsewhere (RandallGoodwin et al., 2015; Yager et al., 2016).

Chlorophyll $a(\mathrm{Chl} a)$ concentration was highest in the top $40 \mathrm{~m}$ of the water column and where temperatures were elevated, with St. 57.21 and 57.35 as exceptions (Fig. 2). Phaeocystis antarctica likely represented most of the phytoplankton contribution to Chl $a$ followed by diatom (Table S1, Alderkamp et al., 2015; Yager et al., 2016). Dinoflagellates and ciliates made up most of the microzooplankton biomass (Table S1). Subsurface peaks in dinoflagellate and particularly ciliate biomass occurred below the chl $a$ max. at stations closer to the ice shelf and in the wake of the drifting iceberg. Dinoflagellate biomass was also high at St. 35, while elevated surface ciliate biomass occurred at St. 68 at the fringe of the polynya.

\subsection{Microzooplankton community patterns and environment}

The correlation between environmental parameters and microzooplankton community was tested both against indices of community structure (species richness, diversity, eveness) and composition (Bray-Curtis dissimilarity). Overall, ciliate biomass was correlated to most environmental 
182 variables measured, while dinoflagellate biomass and evenness in microzooplankton size distribution

183 was correlated to all (Table 1). Depth was likely a main factor driving community structure (based on

184 microscopy), as negative correlations were observed with variables that generally increase with depth

185 (salinity, dissolved inorganic nitrogen DIN), and positive correlations with variables decreasing with

186 depth. Species richness and diversity displayed similar patterns and were generally positively

187 correlated to heterotrophic nanoflagellate (HNF) abundance. Species richness also increased with chl $a$

188 and concentration of pigment markers for diatoms (fucoxanthin) and prymnesiophytes, such as

189 Phaeocystis spp. (19'-hexanoyloxyfucoxanthin).

The environmental variables that best explained the microzooplankton community composition patterns were depth, bacterial and HNF abundances, and fucoxanthin concentration $(\mathrm{BEST}, \mathrm{Rho}=$

$0.72, \mathrm{p}=0.01)$. Distance based linear models $($ DistLM) found microzooplankton community

composition to be related to all environmental parameters tested (depth, temperature, salinity, density,

PAR, total DIN, chl $a$, bacterial and HNF abundance, 19'-hexanoyloxyfucoxanthin and fucoxanthin

concentration, $\mathrm{p}<0.005)$. HNF and bacterial abundance generated the lowest AICc score thus

196 explaining most of the variance in microzooplankton community composition $\left(\mathrm{AICc}=192.81, \mathrm{R}^{2}=\right.$ 197 0.38, Fig. 3).

\subsection{Taxonomy and distribution}

Microscopy-based microzooplankton community dissimilarities were greater between the

200 surface and depth of fluorescence max. (DFM) than between sampling stations $(\mathrm{p}=0.12)$, but differed

201 significantly from the deeper samples $(\mathrm{p}<0.03$, Fig. 3). Station 68 located at the edge of the polynya 
202

203

204

205

206

207

208

209

210

211

212

213

214

215

216

217

218

219

220

221

222

223

and St. 13, which had the lowest species richness and diversity of all stations (data not shown), displayed the least similarity to the communities seen at the other stations (Fig. 3).

Microscopy counts indicated that the community was dominated by dinoflagellates constituting on average $58 \%$ of the microzooplankton biomass (Fig. 4, Table S1). Gymnodinium spp. and heterotrophic Gyrodinium spirale and Protoperidinium spp. (mainly P. depressum) accounted for $87 \%$ of the dinoflagellate biomass, but differed in distribution patterns (Fig. 4A). Gyrodinium spp. tended to decrease with distance to the ice shelf, while G. spirale and Protoperidinium spp. showed inverse distributions between transects 1 and 2 . The ciliate community was dominated by heterotrophic tintinnids, Strombilidium spp. (mainly S. epacrum and S. spiralis) and mixotrophic Strombidium spp. that together contributed with $91 \%$ of the ciliates biomass (Fig. 4B). Along transect 1 tintinnid and Strombidium spp. biomass increased with distance to the ice shelf while Strombilidium spp. tended to decrease. However, on transect 2 both tintinnids and Strombilidium spp. represented the highest biomass on St. 57.35. The heterotrophic Didinium nasutum represented the highest biomass only on station 48. Station 13 and 57.21 were characteristic in featuring fewer microzooplankton than adjacent stations, and the ciliate community at St. 13 was dominated solely by tintinnids (Fig. 4).

The 18S rRNA analysis confirmed that the microzooplankton community was dominated by dinoflagellates representing on average $85 \%$ of the microzooplankton amplicons at surface and DFM and $68 \%$ in deeper waters $(>400 \mathrm{~m}$, Fig. S1). The main OTU found in all samples was related to the dinoflagellate SL163A10 (99\% identity) closely related to Gymnodiniales (Fig. 5A). Other important dinoflagellates were closely related to Peridiniales increasing with depth and other Gymnodiniales related to Gymnodinium sp. and Gyrodinium sp. (Fig. 5A, S1). Ciliates represented on average 15\% of the microzooplankton related OTUs at surface and DFM and their contribution increased to $\sim 32 \%$ at 
depth. The dominant ciliate OTUs were closely related to potential parasites from the Ventrata order

(Fig. 5B, S1). Other abundant ciliate OTUs were related to Choreotrichia, Oligotrichia, and Haptoria.

Resemblance analysis of 12 microzooplankton taxonomic orders identified in either the sequencing or microscopy dataset (Fig. 4, S1, Table S1) from 6 overlapping samplings (St. 48, 50, 57.21 at surface and DFM, Fig. 1) showed no significant correlation between their relative abundance in the 18S rRNA amplicon dataset and biomass $(\mathrm{Rho}=0.46, \mathrm{p}=0.11)$ or cell abundance $(\mathrm{Rho}=0.4, \mathrm{p}$ $=0.08)$.

\subsection{Succession during an induced Phaeocystis bloom}

During the course of the induced experimental Phaeocystis bloom, no major differences were observed between filtered and unfiltered water. No metazoans were observed during the experiment in any treatment. Chl $a$ increased about 5-folds in both treatments over the course of the incubation (Fig. 6A). The increase in chl $a$ was mainly associated with a 4-fold increase in Phaeocystis antarctica reached an average biomass of $750 \mu \mathrm{g} \mathrm{C}^{-1}$ on day 15 . Many large $P$. antarctica colonies were observed in all replicate containers. Diatoms also increased up to an estimated biomass of $250 \mu \mathrm{g} \mathrm{C}^{-1}$ with a faster growth rate than $P$. antarctica (Table S2). The dominant dinoflagellates Gymnodinium spp. and Gyrodinium spirale increased over the course of the bloom, especially Gymnodinium spp., with a growth rate of $\sim 0.18 \mathrm{~d}^{-1}$, reaching a biomass of $100 \mu \mathrm{g} \mathrm{Cl}^{-1}$ in the unfiltered treatments (Fig. 6.B, C, D, Table S2). The most abundant dinoflagellate OTU was related to SL163A10 (data not shown). Other dinoflagellate taxa remained stable or decreased during the experiment (Fig. 6D, Table S2). Tintinnids were the main group of ciliates responding to the extended bloom with a biomass of up to $8 \mu \mathrm{g} \mathrm{Cl}^{-1}$ and a growth rate of $0.21 \mathrm{~d}^{-1}$ in the unfiltered treatment (Fig. 6E, F, Table S2). Other 
245 ciliates (e.g. Strobilidium spp. and Strombidium spp.) decreased slightly during the course of the 246 experiment.

\section{Discussion}

250

251

252

253

254

255

256

257

258

259

260

261

262

263

264

265

In early summer, the open waters of the Amundsen Sea polynya (ASP) harbor extensive episodic blooms of the colony forming prymnesiophyte Phaeocystis sp. (Alderkamp et al., 2012;

Arrigo et al., 2012). At the time of sampling in summer 2010-2011, the full net primary production was principally exported to deeper water or grazed by microzooplankton (Yager et al., 2016). Our study suggests that grazing pressure on the bloom in the ASP was mainly due to dinoflagellates known to be mixotrophs and heterotrophs, and hence our work provides further insights about the composition and dynamics of the microzooplankton community in the poorly explored polynyas of the Southern Ocean (SO).

\subsection{Patterns in microzooplankton community structure}

Known heterotrophic and mixotrophic dinoflagellates, mainly Gymnodinium, Gyrodinium and Protoperidinium, dominated the ASP microzooplankton community. These three genera were also dominant in the ASP in time periods following after the present study (Yang et al., 2016) and are known to be widely distributed across the SO (Stoecker et al., 1995; Safi et al., 2007; Pearce et al., 2008; Garzio \& Steinberg, 2013; Christaki et al., 2015). Less abundant ciliates known to be heterotrophic or mixotrophic, particularly loricate tintinnids and aloricate Strobilidium spp. and Strombidium spp., also constituted an important part of the community. This differs from other studies in the Amundsen Sea (AS) where Oligotrichs; mainly Strombidium spp. and Tontonia spp., and the 
266 Choreotrich; Lohmanniella oviformis dominated the ciliate assemblage while tintinnids were few and

267 Strobilidium spp. was absent (Dolan et al., 2013; Jiang et al., 2014; Jiang et al., 2016). Strobilidium and

268 Lohmanniella are morphologically similar and may have been misidentified in either our study or by

269 (Jiang et al., 2014; Jiang et al., 2016). High abundance of both genera have been reported from the AS

270 (Wickham et al., 2011) and the Kerguelen area in the SO (Christaki et al., 2015).

271 Microzooplankton community structure changed with depth and distance to the ice shelf, and

272 positively correlated mainly with abundance of heterotrophic nanoflagellates (HNF), bacteria and

273 concentration of the diatom pigment marker fucoxanthin. These relationships may be explained by all

274 trophic levels responding to the same environmental drivers or by direct predator-prey relationships.

275 Low picophytoplankton biomass in the ASP (Lee et al., 2012; Yang et al., 2016) may have resulted in a

276 dietary shift for HNF to primarily graze on bacteria (Gonzalez et al., 1990; Pearce et al., 2011) and in

277 turn being grazed by heterotrophic dinoflagellates and ciliates (Kuparinen \& Bjornsen, 1992; Jürgens et

278 al., 1996). Some ciliates are also capable of grazing directly on bacteria (Sherr \& Sherr, 2002). Larger

279 diatoms $(>15 \mu \mathrm{m}$ in length), which accounted for most of the diatom biomass (data not shown), are

280 mainly grazed by heterotrophic dinoflagellates (Hansen, 1992; Sherr \& Sherr, 2007; Grattepanche et

281 al., 2011). Thus, changes in diatom contribution to a Phaeocystis dominated phytoplankton community,

282 as well as HNF abundance are expected to propagate into the microzooplankton community structure.

283 Although mesozooplankton biomass was generally low, predation likely affected the microzooplankton

284 assemblage at St. 13, which experienced the highest mesozooplankton grazing (Wilson et al., 2015;

285 Yager et al., 2016)and where the ciliates were almost exclusively tintinnids, a group known to be more

286 resistant to metazoan predation (Stoecker, 2012). Lastly, upwelling of deeper water masses 
downstream of a drifting iceberg (St. 57.21) and contribution of sea ice melt water (St. 68) (RandallGoodwin et al., 2015; Dinasquet et al., 2017) was seen to affect biomass and community structure.

\subsection{Morphological and molecular analyses of microzooplankton composition and dynamics}

While morphological and molecular information on microzooplankton are generally not directly comparable (Medinger et al., 2010; Monchy et al., 2012; Christaki et al., 2015) due to large variations in 18S rDNA copies per organism (Zhu et al., 2005; Gong et al., 2013) and the limited taxonomic resolution provided by morphology, the two methods are complementary.

Both methods showed that the microzooplankton community was dominated by dinoflagellates, in particular the Gymnodiniaceae family dominated at most stations. Surprisingly, Peridiniales-related sequences were few despite representing a substantial fraction of the dinoflagellate biomass, possibly due to relatively inefficient RNA extraction from thecate dinoflagellates. Members of the Gymnodicianiceae family have very similar morphological attributes, which makes them difficult to distinguish (Gast et al., 2006). Here, through sequencing, the dominant dinoflagellates were identified as closely related to SL163A10; a species also very abundant in the Ross Sea Polynya (Gast et al., 2006) and the Antarctic peninsula (Luria et al., 2014). This dinoflagellate was also found to be the dominant protist in the ASP sea ice at the time of sampling, where it may play an important ecological role (Torstensson et al., 2015).

Whereas both methods reported similar proportions of ciliates and dinoflagellates, the detailed taxonomic information was not comparable. For instance, Strombidium spp., Strobilidium spp. and tintinnids had the highest biomasses, but the sequencing did not match their relative biomass or abundance contribution. Tintinnids, which are detectable by both methods (Bachy et al., 2011), were 
underrepresented in our sequencing dataset. Tintinnids, Strombidium spp. and Strobilidium spp. have distinct morphological features and it is unlikely that they were misidentified through microscopy. On the other hand, ciliates related to the Oligohymenophorea class were the most abundant in the sequencing dataset especially in deep waters, as found in other studies (Zoccarato et al., 2016; Zhao et al., 2017). They may have been overlooked in the microscope as their pelagic stage is usually a dormant cyst like form, which is difficult to identify. Interestingly, many taxa related to Oligohymenophorea are potential symbionts and parasites of crustaceans (Gómez-Gutiérrez et al., 2006; Gomez-Gutierrez et al., 2012), but their importance for zooplankton population dynamics in the Southern Ocean is so far unknown.

\subsection{Microzooplankton ecology during a Phaeocystis bloom in the ASP}

Phaeocystis antarctica was by far the most abundant phytoplankton in the ASP at the time of sampling (Alderkamp et al., 2015; Yager et al., 2016, Table S1). Particular interest have been given to Phaeocystis due to its production of DMSP (reviewed in Liss et al., 1994) and high rates of primary production (DiTullio et al., 2000; Alderkamp et al., 2012). Different species of this prymnesiophyte are ubiquitous in marine environments where they can form dense blooms (Schoemann et al., 2005) has a global distribution and is found as different species in very different marine environments. Rapid increase of Phaeocystis may in part be ascribed to its capacity to form large colonies not readily grazed on by micro- and mesozooplankton (Caron et al., 2000; Jakobsen \& Tang, 2002; Nejstgaard et al., 2007; Grattepanche et al., 2011). The capacity of some microzooplankton species, such as Gyrodinium spp., Gymnodinium spp. and tintinids, to graze on single cells and small colonies of Phaeocystis (Admiraal \& Venekamp, 1986; Bjørnsen \& Kuparinen, 1991; Stoecker et al., 1995; Nejstgaard et al., 2007; Grattepanche et al., 2010), would nevertheless explain the dominance of these species at the time 
of sampling. Gyrodinium spp., Gymnodinium spp. and tintinids were also found to co-dominate during

331

332

333

334

335

336

337

338

339

Phaeocystis blooms in McMurdo Sound and the North Sea (Weisse \& Scheffel-Möser, 1990; Stoecker

et al., 1995). The intense phytoplankton growth observed in the induced bloom experiment, despite an increased dominance of known Phaeocystis grazers, suggested that P. antarctica were not controlled by microzooplankton herbivory possibly because of low grazing rates (Caron et al., 2000; Yager et al., 2016) at this colonial stage of the bloom. However, higher grazing rates of $90 \% \mathrm{~d}^{-1}$ were observed later in the ASP (Yang et al., 2016), suggesting the capacity of microzooplankton to control the later stage of the Phaeocystis bloom where colonies breakup into single cells. Single Phaeocystis cells are more vulnerable to predation and are often released from colonies later in the season possibly when nutrients become limiting (Jakobsen \& Tang, 2002; Smith et al., 2003; Nejstgaard et al., 2007).

Most of the ciliates we observed in the ASP were heterotrophs with the ability to graze on single cell Phaeocystis and small diatoms (Grattepanche et al., 2010; Dolan et al., 2013). The dominant dinoflagellate Gymnodinium spp. is capable of grazing on small Phaeocystis colonies (Grattepanche et al., 2011). In the present study, the most abundant microzooplankton Gymnodiniaceae SL163A10 engage in kleptoplasty of $P$. antarctica chloroplasts (Gast et al., 2007). This dinoflagellate is ubiquitous in the SO, in waters and sea ice (Gast et al., 2006; Luria et al., 2014; Torstensson et al., 2015, this study), suggesting that its mixotrophic life strategy is highly successful. The observed microzooplankton community shift towards the dominance of Gymnodinium spp. (83\% of microzooplankton biomass) in the microcosm experiment also underlines this species ability to thrive in an environment dominated by Phaeoystis colonies. Nevertheless, the relative importance of its primary vs. secondary production within the food web is not known. Mixotrophic dinoflagellates are important phytoplankton grazers in the SO open waters and semi-enclosed polynyas (Gast et al., 2006; 
352 Christaki et al., 2015) and potentially important prey for zooplankton grazers, although they did not 353 sustain high biomass of zooplankton in the ASP (Lee et al., 2013; Wilson et al., 2015).

During this study, colonial Phaeocystis were grazed at low rates, but sustained a high biomass of specialized microzooplankton capable of grazing on them. Although taxa known to be mixotrophic were important, heterotrophy appeared to be the main life strategy for the microzooplankton. The presence of Phaeocystis colonies appeared to determine the key microzooplankton taxa, while other potential prey seemed more important for shaping the community composition of less abundant taxa within the ASP. The early shift in community composition observed during the induced bloom experiment as well as the major differences in microzooplankton community composition and biomass observed few days later in the polynya (Jiang et al., 2014; Yang et al., 2016) are consistent with the pronounced and selective impact of Phaeocystis blooms on growth, biomass and composition of the cooccurring microzooplankton. Whereas these interactions undoubtedly affect biogeochemical nutrient vertical carbon export remains to be addressed. 


\section{Acknowledgments}

We gratefully acknowledge the support from captain and crew of the RVIB Nathaniel B. Palmer,

371 the Raytheon support team onboard and our chief scientists P. Yager. We also thank K. Arrigo's team

372 for sharing pigment data. Oden Southern Ocean, SWEDARP 2010/11, was organized by the Swedish

373 Polar Research Secretariat and National Science Foundation Office of Polar Programs. This work was

374 supported by the Swedish Research Council [grant 2008-6430] to S. Bertilsson and L. Riemann and

375 [grant 824-2008-6429] to P.-O. Moksnes and J. Havenhand) and by the US National Science

376 Foundation through the ASPIRE project [NSF OPP-0839069] to P. Yager.

378 Declarations of interest: none 
379

380

381

382

383

384

385

386

387

388

389

390

391

392

393

394

395

396

397

398

399

400

401

402

403

404

405

406

407

408

409

410

411

412

413

414

\section{References}

Admiraal, W., Venekamp, L.A.H., 1986. Significance of tintinnid grazing during blooms of Phaeocystis pouchetii (haptophyceae) in Dutch coastal waters. Netherlands Journal of Sea Research, 20, 61-66.

Alderkamp, A.-C., van Dijken, G.L., Lowry, K.E., Connelly, T.L., Lagerström, M., Sherrell, R.M., Haskins, C., Rogalsky, E., Schofield, O., Stammerjohn, S.E., Yager, P.L., Arrigo, K.R., 2015. Fe availability drives phytoplankton photosynthesis rates during spring bloom in the Amundsen Sea Polynya, Antarctica. Elem Sci Anth, 3, 000043.

Alderkamp, A.C., Mills, M.M., van Dijken, G.L., Laan, P., Thuroczy, C.E., Gerringa, L.J.A., De Baar, H.J.W., Payne, C.D., Visser, R.J.W., Buma, A.G.J., Arrigo, K.R., 2012. Iron from melting glaciers fuels phytoplankton blooms in the Amundsen Sea (Southern Ocean): Phytoplankton characteristics and productivity. Deep-Sea Research Part Ii-Topical Studies in Oceanography, 71-76, 32-48.

Anderson, M.J., Gorley, R.N., Clarke, K.R., 2008. PERMANOVA for PRIMER. Guide to software and statistical methods.

Arrigo, K.R., Lowry, K.E., van Dijken, G.L., 2012. Annual changes in sea ice and phytoplankton in polynyas of the Amundsen Sea, Antarctica. Deep-Sea Research Part Ii-Topical Studies in Oceanography, 71-76, 5-15.

Arrigo, K.R., van Dijken, G., Long, M., 2008. Coastal Southern Ocean: A strong anthropogenic CO2 sink. Geophysical Research Letters, 35.

Arrigo, K.R., van Dijken, G.L., 2003. Phytoplankton dynamics within 37 Antarctic coastal polynya systems. Journal of Geophysical Research-Oceans, 108.

Bachy, C., Lopez-Garcia, P., Vereshchaka, A., Moreira, D., 2011. Diversity and vertical distribution of microbial eukaryotes in the snow, sea ice and seawater near the North Pole at the end of the polar night. Frontiers in Microbiology, 2.

Bjørnsen, P., Kuparinen, J., 1991. Growth and herbivory by heterotrophic dinoflagellates in the Southern Ocean, studied by microcosm experiments. Marine Biology, 109, 397-405.

Calbet, A., Landry, M.R., 2004. Phytoplankton growth, microzooplankton grazing, and carbon cycling in marine systems. Limnology and Oceanography, 49, 51-57.

Caporaso, J.G., Kuczynski, J., Stombaugh, J., Bittinger, K., Bushman, F.D., Costello, E.K., Fierer, N., Pena, A.G., Goodrich, J.K., Gordon, J.I., Huttley, G.A., Kelley, S.T., Knights, D., Koenig, J.E., Ley, R.E., Lozupone, C.A., McDonald, D., Muegge, B.D., Pirrung, M., Reeder, J., Sevinsky, J.R., Turnbaugh, P.J., Walters, W.A., Widmann, J., Yatsunenko, T., Zaneveld, J., Knight, R., 2010.

QIIME allows analysis of high-throughput community sequencing data. Nat Methods, 7, 335-336.

Caron, D.A., Dennett, M.R., Lonsdale, D.J., Moran, D.M., Shalapyonok, L., 2000. Microzooplankton herbivory in the Ross Sea, Antarctica. Deep Sea Research Part II: Topical Studies in Oceanography, 47, 3249-3272. 
Christaki, U., Courties, C., Massana, R., Catala, P., Lebaron, P., Gasol, J.M., Zubkov, M.V., 2011. Optimized routine flow cytometric enumeration of heterotrophic flagellates using SYBR Green I. Limnology and Oceanography-Methods, 9, 329-339.

Christaki, U., Georges, C., Genitsaris, S., Monchy, S., 2015. Microzooplankton community associated with phytoplankton blooms in the naturally iron-fertilized Kerguelen area (Southern Ocean). Fems Microbiology Ecology, 91.

Clarke, K.R., Warwick, P.E., 2001. Change in Marine Communities: An Approach to Statistical Analysis and Interpretation.

Dinasquet, J., Richert, I., Logares, R., Yager, P., Bertilsson, S., Riemann, L., 2017. Mixing of water masses caused by a drifting iceberg affects bacterial activity, community composition and substrate utilization capability in the Southern Ocean. Environmental Microbiology, 19, 2453-2467.

DiTullio, G.R., Grebmeier, J.M., Arrigo, K.R., Lizotte, M.P., Robinson, D.H., Leventer, A., Barry, J.P., VanWoert, M.L., Dunbar, R.B., 2000. Rapid and early export of Phaeocystis antarctica blooms in the Ross Sea, Antarctica. Nature, 404, 595-598.

Dolan, J.R., Jin Yang, E., Hoon Lee, S., Young Kim, S., 2013. Tintinnid ciliates of Amundsen Sea (Antarctica) plankton communities. Polar Research, 32, 19784.

Edgar, R.C., 2010. Search and clustering orders of magnitude faster than BLAST. Bioinformatics, 26, 2460-2461.

Froneman, P., Perissinoto, R., 1996. Microzooplankton grazing in the southern ocean: Implications for the carbon cycle. Marine Ecology-Pubblicazioni Della Stazione Zoologica di Napoli I, 17, 99-115.

Garzio, L.M., Steinberg, D.K., 2013. Microzooplankton community composition along the Western Antarctic Peninsula. Deep Sea Research Part I: Oceanographic Research Papers, 77, 36-49.

Gasol, J.M., del Giorgio, P.A., 2000. Using flow cytometry for counting natural planktonic bacteria and understanding the structure of planktonic bacterial communities. Scientia Marina, 64, 197-224.

Gast, R.J., Moran, D.M., Beaudoin, D.J., Blythe, J.N., Dennett, M.R., Caron, D.A., 2006. Abundance of a novel dinoflagellate phylotype in the Ross Sea, Antarctica. Journal of Phycology, 42, 233-242.

Gast, R.J., Moran, D.M., Dennett, M.R., Caron, D.A., 2007. Kleptoplasty in an Antarctic dinoflagellate: caught in evolutionary transition? Environmental Microbiology, 9, 39-45.

Gómez-Gutiérrez, J., Peterson, W.T., Morado, J.F., 2006. Discovery of a ciliate parasitoid of euphausiids off Oregon, USA: Collinia oregonensis n. sp.(Apostomatida: Colliniidae). Diseases of aquatic organisms, 71, 33-49.

Gomez-Gutierrez, J., Strüder-Kypke, M., Lynn, D., Shaw, T., Aguilar-Méndez, M., López-Cortés, A., Martínez-Gómez, S., Robinson, C., 2012. Pseudocollinia brintoni gen. nov., sp. nov.(Apostomatida: Colliniidae), a parasitoid ciliate infecting the euphausiid Nyctiphanes simplex. Diseases of aquatic organisms, 99, 57-78.

Gong, J., Dong, J., Liu, X., Massana, R., 2013. Extremely High Copy Numbers and Polymorphisms of the rDNA Operon Estimated from Single Cell Analysis of Oligotrich and Peritrich Ciliates. Protist, $164,369-379$. 
Gonzalez, J.M., Sherr, E.B., Sherr, B.F., 1990. Size-selective grazing on bacteria by natural assemblages of estuarine flagellates and ciliates. Applied and Environmental Microbiology, 56, 583-589.

Grattepanche, J.-D., Breton, E., Brylinski, J.-M., Lecuyer, E., Christaki, U., 2010. Succession of primary producers and micrograzers in a coastal ecosystem dominated by Phaeocystis globosa blooms. Journal of Plankton Research, 33, 37-50.

Grattepanche, J.-D., Vincent, D., Breton, E., Christaki, U., 2011. Microzooplankton herbivory during the diatom-Phaeocystis spring succession in the eastern English Channel. Journal of Experimental Marine Biology and Ecology, 404, 87-97.

Guillou, L., Bachar, D., Audic, S., Bass, D., Berney, C., Bittner, L., Boutte, C., Burgaud, G., de Vargas, C., Decelle, J., Del Campo, J., Dolan, J.R., Dunthorn, M., Edvardsen, B., Holzmann, M., Kooistra, W.H., Lara, E., Le Bescot, N., Logares, R., Mahe, F., Massana, R., Montresor, M., Morard, R., Not, F., Pawlowski, J., Probert, I., Sauvadet, A.L., Siano, R., Stoeck, T., Vaulot, D., Zimmermann, P., Christen, R., 2013. The Protist Ribosomal Reference database (PR2): a catalog of unicellular eukaryote small sub-unit rRNA sequences with curated taxonomy. Nucleic Acids Res, 41, D597604.

Hansen, P.J., 1992. Prey size selection, feeding rates and growth dynamics of heterotrophic dinoflagellates with special emphasis on Gyrodinium spirale. Marine Biology, 114, 327-334.

Jakobsen, H.H., Tang, K.W., 2002. Effects of protozoan grazing on colony formation in Phaeocystis globosa (Prymnesiophyceae) and the potential costs and benefits. Aquatic Microbial Ecology.

Jespersen, A.M., Christoffersen, K., 1987. Measurements of chlorophyll-a from phytoplankton using ethanol as extraction solvent. Archiv Fur Hydrobiologie, 109, 445-454.

Jiang, Y., Liu, Q., Yang, E.J., Wang, M., Kim, Tae W., Cho, K.-H., Lee, S., 2016. Pelagic ciliate communities within the Amundsen Sea polynya and adjacent sea ice zone, Antarctica. Deep Sea Research Part II: Topical Studies in Oceanography, 123, 69-77.

Jiang, Y., Yang, E.J., Kim, S.Y., Kim, Y.-N., Lee, S., 2014. Spatial patterns in pelagic ciliate community responses to various habitats in the Amundsen Sea (Antarctica). Progress In Oceanography, 128, 49-59.

Jürgens, K., Wickham, S.A., Rothhaupt, K.O., Santer, B., 1996. Feeding rates of macro- and microzooplankton on heterotrophic nanoflagellates. Limnology and Oceanography, 41, 1833-1839.

Kumar, S., Stecher, G., Tamura, K., 2016. MEGA7: Molecular Evolutionary Genetics Analysis Version 7.0 for Bigger Datasets. Molecular Biology and Evolution, 33, 1870-1874.

Kuparinen, J., Bjornsen, P.K., 1992. Bottom-Up and Top-Down Controls of the Microbial Food Web in the Southern-Ocean - Experiments with Manipulated Microcosms. Polar biology, 12, 189-195. Landry, M.R., Selph, K.E., Brown, S.L., Abbott, M.R., Measures, C.I., Vink, S., Allen, C.B., Calbet, A., Christensen, S., Nolla, H., 2002. Seasonal dynamics of phytoplankton in the Antarctic Polar Front region at $170^{\circ} \mathrm{W}$. Deep Sea Research Part II: Topical Studies in Oceanography, 49, 18431865. 
Lee, D.B., Choi, K.H., Ha, H.K., Yang, E.J., Lee, S.H., Lee, S., Shin, H.C., 2013. Mesozooplankton distribution patterns and grazing impacts of copepods and Euphausia crystallorophias in the Amundsen Sea, West Antarctica, during austral summer. Polar Biology, 36, 1215-1230.

Lee, S.H., Kim, B.K., Yun, M.S., Joo, H., Yang, E.J., Kim, Y.N., Shin, H.C., Lee, S., 2012. Spatial distribution of phytoplankton productivity in the Amundsen Sea, Antarctica. Polar Biology, 35, 1721-1733.

Liss, P.S., Malin, G., Turner, S.M., Holligan, P.M., 1994. Dimethyl sulphide and Phaeocystis: A review. Journal of Marine Systems, 5, 41-53.

Luria, C.M., Ducklow, H.W., Amaral-Zettler, L.A., 2014. Marine bacterial, archaeal and eukaryotic diversity and community structure on the continental shelf of the western Antarctic Peninsula. Aquat.Microb.Ecol., 73, 107-121.

McArdle, B.H., Anderson, M.J., 2001. Fitting multivariate models to community data: A comment on distance-based redundancy analysis. Ecology, 82, 290-297.

Medinger, R., Nolte, V., Pandey, R.V., Jost, S., Ottenwalder, B., Schlotterer, C., Boenigk, J., 2010. Diversity in a hidden world: potential and limitation of next-generation sequencing for surveys of molecular diversity of eukaryotic microorganisms. Molecular Ecology, 19, 32-40.

Menden-Deuer, S., Lessard, E.J., 2000. Carbon to Volume Relationships for Dinoflagellates, Diatoms, and Other Protist Plankton. Limnology and Oceanography, 45, 569-579.

Monchy, S., Grattepanche, J.D., Breton, E., Meloni, D., Sanciu, G., Chabé, M., Delhaes, L., Viscogliosi, E., Sime-Ngando, T., Christaki, U., 2012. Microplanktonic Community Structure in a Coastal System Relative to a Phaeocystis Bloom Inferred from Morphological and Tag Pyrosequencing Methods. Plos One, 7, e39924.

Nejstgaard, J.C., tang, K.W., Steinke, M., Dutz, J., Koski, M., Antajan, E., Long, J.D., 2007.

Zooplankton grazing on Phaeocystis: a quantitative review and future challenges. Biogeochemistry, 83, 147-172.

Olenina, I., 2006. Biovolumes and size-classes of phytoplankton in the Baltic Sea.

Pearce, I., Davidson, A.T., Thomson, P.G., Wright, S., van den Enden, R., 2011. Marine microbial ecology in the sub-Antarctic Zone: Rates of bacterial and phytoplankton growth and grazing by heterotrophic protists. Deep Sea Research Part II: Topical Studies in Oceanography, 58, 22482259.

Pearce, I., Davidson, A.T., Wright, S., van den Enden, R., 2008. Seasonal changes in phytoplankton growth and microzooplankton grazing at an Antarctic coastal site. Aquatic Microbial Ecology, 50, 157-167.

Pritchard, H.D., Arthern, R.J., Vaughan, D.G., Edwards, L.A., 2009. Extensive dynamic thinning on the margins of the Greenland and Antarctic ice sheets. Nature, 461, 971-975.

Quast, C., Pruesse, E., Yilmaz, P., Gerken, J., Schweer, T., Yarza, P., Peplies, J., Glockner, F.O., 2013. The SILVA ribosomal RNA gene database project: improved data processing and web-based tools. Nucleic Acids Res, 41, D590-596. 
Randall-Goodwin, E., Meredith, M.P., Jenkins, A., Yager, P.L., Sherrell, R.M., Abrahamsen, E.P., Guerrero, R., Yuan, X., Morlock, R.A., Gavahan, K., Alderkam, A.-C., Ducklow, H., Robertson, R., Stammerjohn, S.E., 2015. Freshwater distributions and water mass structure in the Amundsen Sea Polynya region, Antarctica. Elem Sci Anth, 3, 000065.

Reeder, J., Knight, R., 2010. Rapidly denoising pyrosequencing amplicon reads by exploiting rankabundance distributions. Nature methods, 7, 668-669.

Sabine, C.L., Feely, R.A., Gruber, N., Key, R.M., Lee, K., Bullister, J.L., Wanninkhof, R., Wong, C.S., Wallace, D.W.R., Tilbrook, B., Millero, F.J., Peng, T.-H., Kozyr, A., Ono, T., Rios, A.F., 2004. The Oceanic Sink for Anthropogenic $\mathrm{CO}_{2}$. Science, 305, 367-371.

Safi, K.A., Brian Griffiths, F., Hall, J.A., 2007. Microzooplankton composition, biomass and grazing rates along the WOCE SR3 line between Tasmania and Antarctica. Deep Sea Research Part I: Oceanographic Research Papers, 54, 1025-1041.

Sarmiento, J.L., Gruber, N., Brzezinski, M.A., Dunne, J.P., 2004. High-latitude controls of thermocline nutrients and low latitude biological productivity. Nature, 427, 56-60.

Schmoker, C., Hernández-León, S., Calbet, A., 2013. Microzooplankton grazing in the oceans: impacts, data variability, knowledge gaps and future directions. Journal of Plankton Research, 35 , 691-706.

Schoemann, V., Becquevort, S., Stefels, J., Rousseau, V., Lancelot, C., 2005. Phaeocystis blooms in the global ocean and their controlling mechanisms: a review. Journal of Sea Research, 53, 43-66. Sherr, E.B., Sherr, B.F., 2002. Significance of predation by protists in aquatic microbial food webs. Antonie Van Leeuwenhoek International Journal of General and Molecular Microbiology, 81, 293308.

Sherr, E.B., Sherr, B.F., 2007. Heterotrophic dinoflagellates: a significant component of microzooplankton biomass and major grazers of diatoms in the sea. Marine Ecology Progress Series, 352, 187-197.

Sherr, E.B., Sherr, B.F., 2009. Capacity of herbivorous protists to control initiation and development of mass phytoplankton blooms. Aquatic Microbial Ecology, 57, 253-262.

Smith Jr, W.O., Gordon, L.I., 1997. Hyperproductivity of the Ross Sea (Antarctica) polynya during austral spring. Geophysical Research Letters, 24, 233-236.

Smith, W.O., Dennett, M.R., Mathot, S., Caron, D.A., 2003. The temporal dynamics of the flagellated and colonial stages of Phaeocystis antarctica in the Ross Sea. Deep Sea Research Part II: Topical Studies in Oceanography, 50, 605-617.

Stammerjohn, S.E., Maksym, T., Massom, R.A., Lowry, K.E., Arrigo, K.R., Yuan, X., Raphael, M., Randall-Goodwin, E., Sherrell, R.M., Yager, P.L., 2015. Seasonal sea ice changes in the Amundsen Sea, Antarctica, over the period of 1979-2014. Elem Sci Anth, 3, 000055.

Stoeck, T., Bass, D., Nebel, M., Christen, R., Jones, M.D., Breiner, H.W., Richards, T.A., 2010. Multiple marker parallel tag environmental DNA sequencing reveals a highly complex eukaryotic community in marine anoxic water. Molecular ecology, 19 Suppl 1, 21-31. 
600

601

602

603

604

605

Stoecker, D.K., 2012. Predators of Tintinnids. The Biology and Ecology of Tintinnid Ciliates (pp. 122144): John Wiley \& Sons, Ltd.

Stoecker, D.K., Gifford, D.J., Putt, M., 1994. Preservation of marine planktonic ciliates: losses and cell shrinkage during fixation. Marine Ecology Progress Series, 293-299.

Stoecker, D.K., Putt, M., Moisan, T., 1995. Nano-and microplankton dynamics during the spring Phaeocystis sp. bloom in McMurdo Sound, Antarctica. JMBA-Journal of the Marine Biological Association of the United Kingdom, 75, 815-832.

Torstensson, A., Dinasquet, J., Chierici, M., Fransson, A., Riemann, L., Wulff, A., 2015.

Physiochemical control of bacterial and protist community composition and diversity in Antarctic sea ice. Environ.Microbiol., doi:10.1111/1462-2920.12865.

Verity, P.G., 2000. Grazing experiments and model simulations of the role of zooplankton in Phaeocystis food webs. Journal of Sea Research, 43, 317-343.

Weisse, T., Scheffel-Möser, U., 1990. Growth and grazing loss rates in single-celled Phaeocystis sp.(Prymnesiophyceae). Marine Biology, 106, 153-158.

Wickham, S.A., Steinmair, U., Kamennaya, N., 2011. Ciliate distributions and forcing factors in the Amundsen and Bellingshausen Seas (Antarctic). Aquatic Microbial Ecology, 62, 215-230.

Williams, W.J., Carmack, E.C., Ingram, R.G., 2007. Physical oceanography of polynyas. (pp. 55-85): Elsevier.

Wilson, S.E., Swalethorp, R., Kjellerup, S., Wolverton, M.A., Ducklow, H.W., Yager, P.L., 2015. Meso- and macro-zooplankton community structure of the Amunsen Sea Polynya, Antarctica (Summer 2010-2011). Elem Sci Anth, 3, 000033.

Yager, P.L., Sherrell, R.M., Stammerjohn, S.E., Alderkam, A.-C., Schofield, O., Abrahamsen, E.P., Arrigo, K.R., Bertilsson, S., Garay, D.L., Guerrero, K.E., Lowry, K.E., Moknes, P.-O., Ndungu, K., Post, A.F., Randall-Goodwin, E., Riemann, L., Severmann, S., Thatje, S., van Dijken, G.L., Wilson, S., 2012. The Amundsen Sea Polynya International Research Expedition. Oceanography, $25,40-53$.

Yager, P.L., Sherrell, R.M., Stammerjohn, S.E., Ducklow, H.W., Schofield, O., Ingall, E.D., Wilson, S.E., Lowry, K.E., Williams, C.M., Riemann, L., Bertilsson, S., Alderkamp, A.C., Dinasquet, J., Logares, R., Melara, A.J., Mu, L., Newstead, R.G., Post, A.F., Swalethorp, R., van Dijken, G.L., 2016. A carbon budget for the Amundsen Sea Polynya, Antarctica; estmating net community production and export in a highly productive polar ecosystem. Elem Sci Anth, 4.

Yang, E.J., Jiang, Y., Lee, S., 2016. Microzooplankton herbivory and community structure in the Amundsen Sea, Antarctica. Deep Sea Research Part II: Topical Studies in Oceanography, 123, 5868.

Yentsch, C.S., Menzel, D.W., 1963. A method for the determination of phytoplankton chlorophyll and phaeophytin by fluorescence. Deep Sea Research and Oceanographic Abstracts, 10, 221-231.

Zhao, F., Filker, S., Xu, K., Huang, P., Zheng, S., 2017. Patterns and drivers of vertical distribution of the ciliate community from the surface to the abyssopelagic zone in the Western Pacific Ocean. Frontiers in Microbiology, 8, 2559. 
606 Zhu, F., Massana, R., Not, F., Marie, D., Vaulot, D., 2005. Mapping of picoeucaryotes in marine

607 ecosystems with quantitative PCR of the 18S rRNA gene. Fems Microbiology Ecology, 52, 79-92.

608 Zoccarato, L., Pallavicini, A., Cerino, F., Umani, S.F., Celussi, M., 2016. Water mass dynamics shape

609 Ross Sea protist communities in mesopelagic and bathypelagic layers. Progress in Oceanography, $610 \quad 149,16-26$.

611

612 
Table 1: Spearman correlation coefficients between environmental variables and dinoflagellate and ciliate species richness (D), diversity $\left(\mathrm{H}^{\prime}\right)$, evenness ( $\mathrm{J}^{\prime}$ species), size distribution evenness $\left(\mathrm{J}^{\prime}\right.$ size) and biomasses.

\begin{tabular}{llllccc}
\hline & D & $\mathbf{H}^{\prime}$ & $\mathbf{J}^{\prime}$ species & $\mathbf{J}^{\prime}$ size & Dinoflagellates & Ciliates \\
\hline Depth & 0.105 & -0.179 & 0.082 & $-0.535^{* *}$ & $-0.585^{* *}$ & $-0.431^{*}$ \\
Temperature & 0.284 & 0.155 & -0.114 & $0.553^{* *}$ & $0.682^{* *}$ & $0.609^{* *}$ \\
Salinity & $-0.422^{*}$ & $-0.47^{*}$ & -0.143 & $-0.640^{* *}$ & $-0.714^{* *}$ & $-0.544^{* *}$ \\
PAR $^{1}$ & 0.105 & 0.212 & 0.038 & $0.469^{*}$ & $0.515^{* *}$ & $0.461^{* *}$ \\
DIN $^{2}$ & $-0.497^{* *}$ & -0.331 & 0.005 & $-0.692^{* *}$ & $-0.825^{* *}$ & $-0.460^{*}$ \\
Chl $\boldsymbol{a}$ & $0.402^{*}$ & 0.291 & -0.035 & $0.738^{* *}$ & $0.782^{* *}$ & $0.337^{*}$ \\
Fucoxanthin & $0.464^{*}$ & 0.350 & 0.026 & $0.820^{* *}$ & $0.829^{* *}$ & $0.477^{*}$ \\
19'-Hexanoyloxyfucoxanthin $^{\prime *}$ & $0.474^{*}$ & 0.283 & -0.049 & $0.723^{* *}$ & $0.756^{* *}$ & 0.268 \\
HNF $^{3}$ & $0.540^{* *}$ & $0.502^{* *}$ & 0.155 & $0.773^{* *}$ & $0.842^{* *}$ & $0.576^{* *}$ \\
Bacteria & 0.206 & 0.117 & -0.169 & $0.416^{*}$ & $0.556^{* *}$ & 0.012 \\
\hline
\end{tabular}

$* \mathrm{p}<0.05, * * \mathrm{p}<0.01,{ }^{1}$ Phytosynthetically Active Radiation, ${ }^{2}$ Dissolved Inorganic Nitrogen, ${ }^{3}$ Heterotrophic Nanoflagellates 


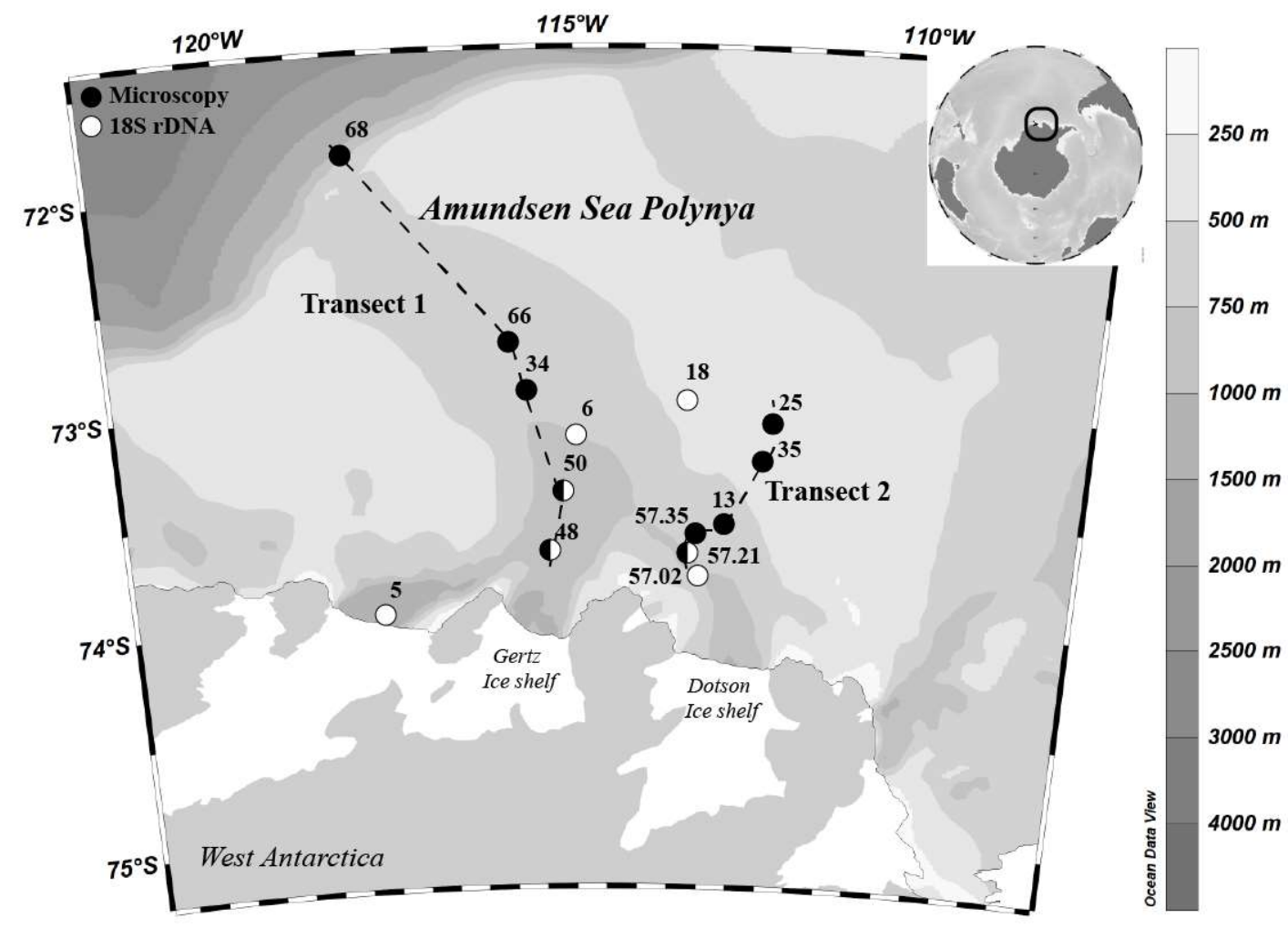

Figure 1: Location of the ASPIRE stations, sampled for microscopy analyses $(\bullet)$ and 18S rDNA (०). Depth contours are illustrated in gray scale. Station numbers are indicated. 


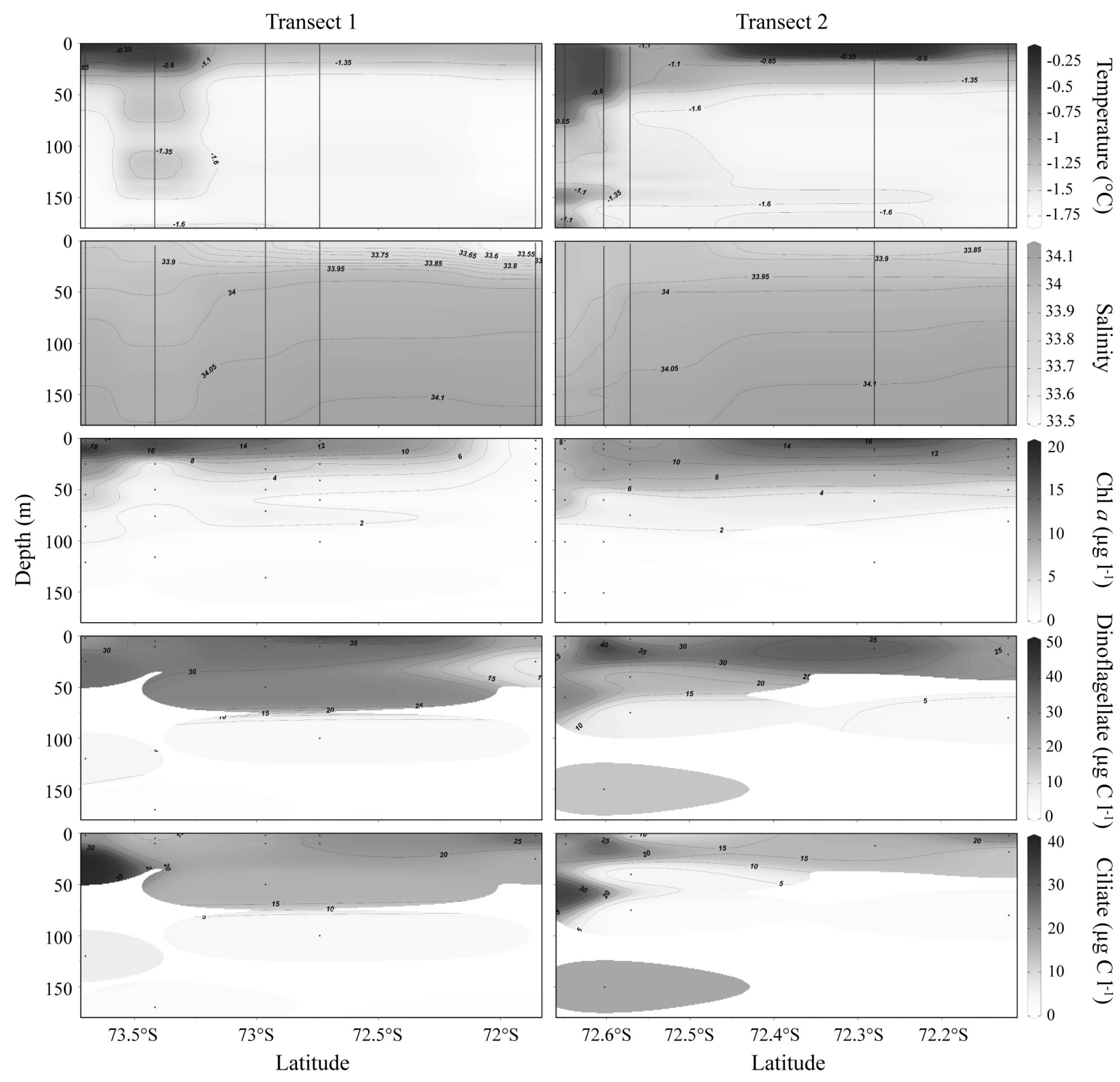

Figure 2: Vertical distribution patterns of temperature, salinity, chl $a$, dinoflagellate and ciliate biomass along two latitudinal transects crossing the polynya. Data also presented in Yager et al. (2016). 


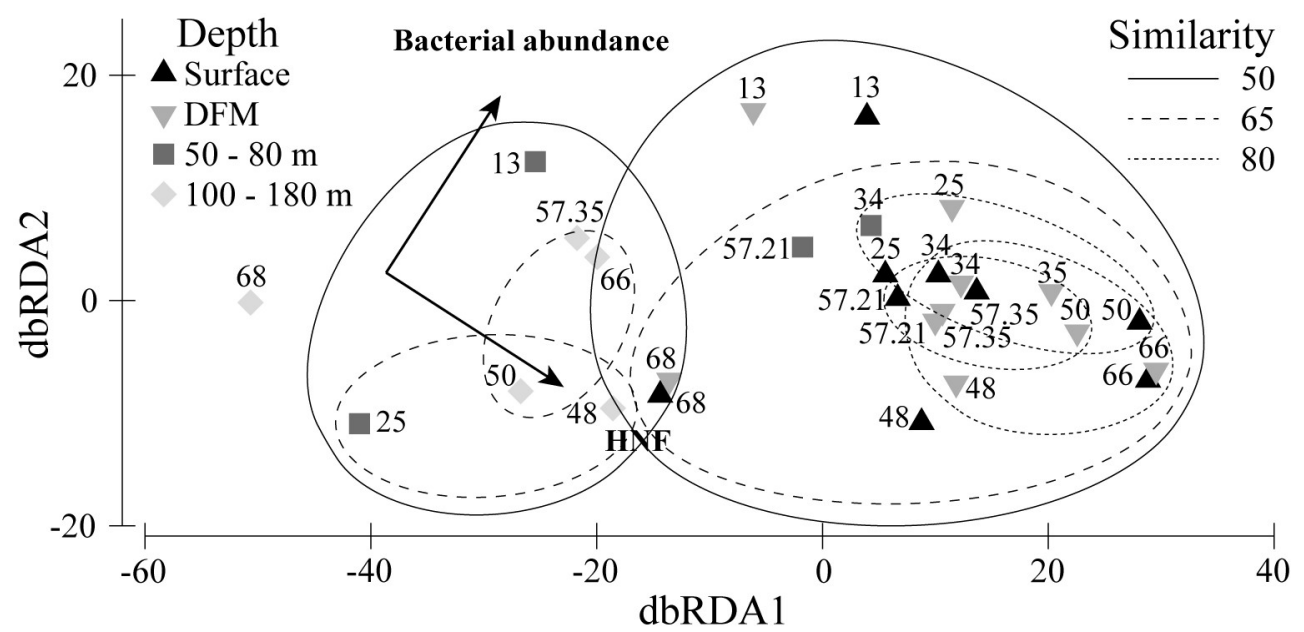

Figure 3: Distance based linear modelling (DistLM) plot on Bray-Curtis similarities of log transformed ciliate and dinoflagellate species biomass data at 28 sampling points in relation to $\log$ transformed and normalized environmental parameters. dbRDA1 explained $88.3 \%$ of fitted and $34 \%$ of total variation while dbRDA 2 explained $11.7 \%$ and $4.5 \%$, respectively. Overlaid is community similarity levels based on Bray-Curtis resemblance matrices. Station numbers are indicated. 
A.



DFM



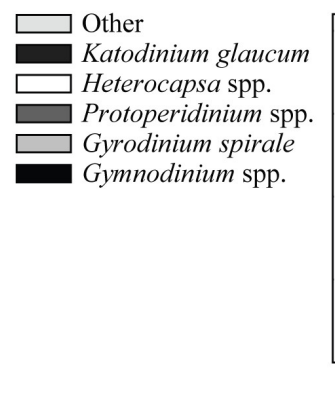

B. Surface

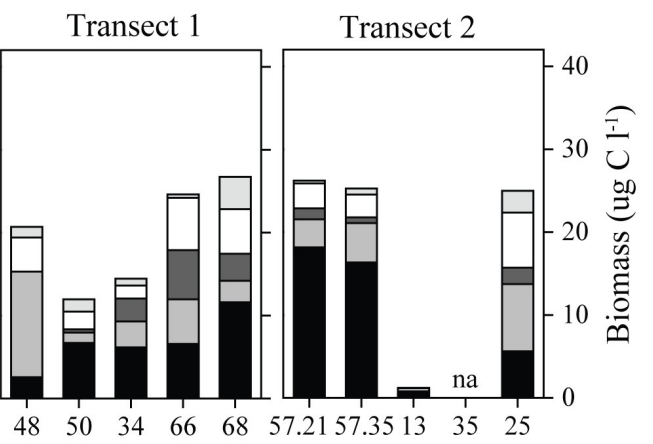

DFM

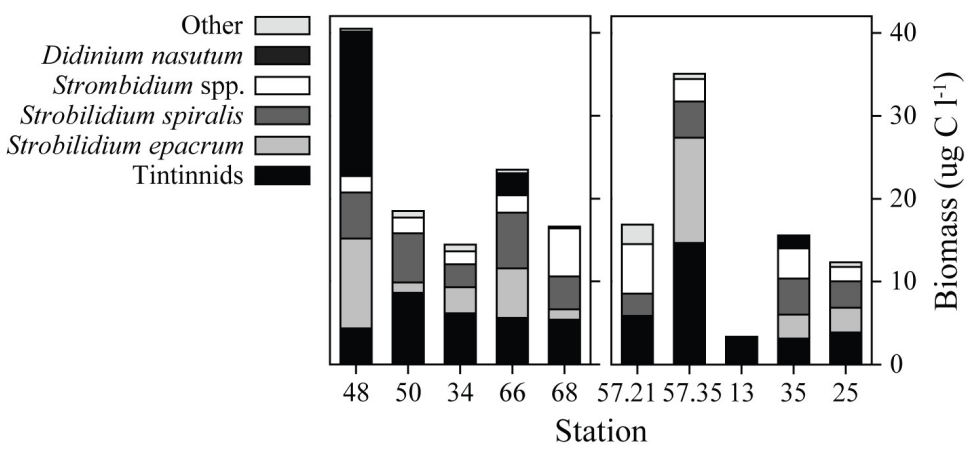

Figure 4: Biomass distribution of dominant dinoflagellate $(\mathrm{A})$ and ciliate $(\mathrm{B})$ taxa along two transects at the surface $(2-5 \mathrm{~m})$ and depth of fluorescence max. (DFM, $10-40 \mathrm{~m}$ ). 
A.

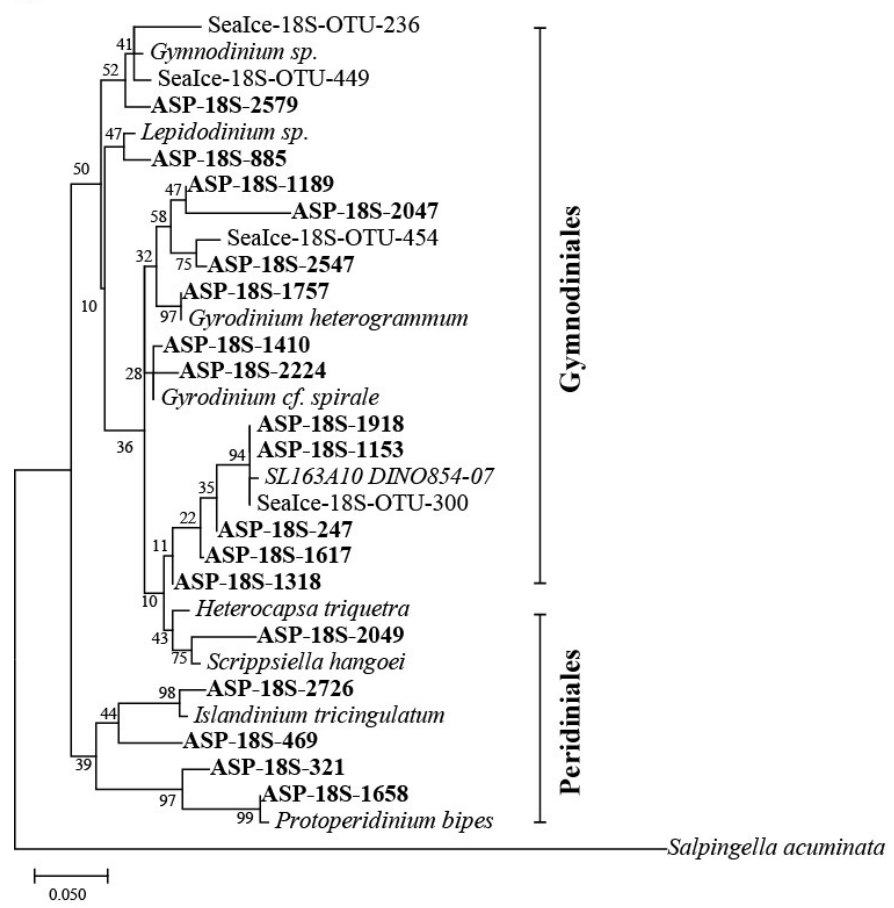

B.

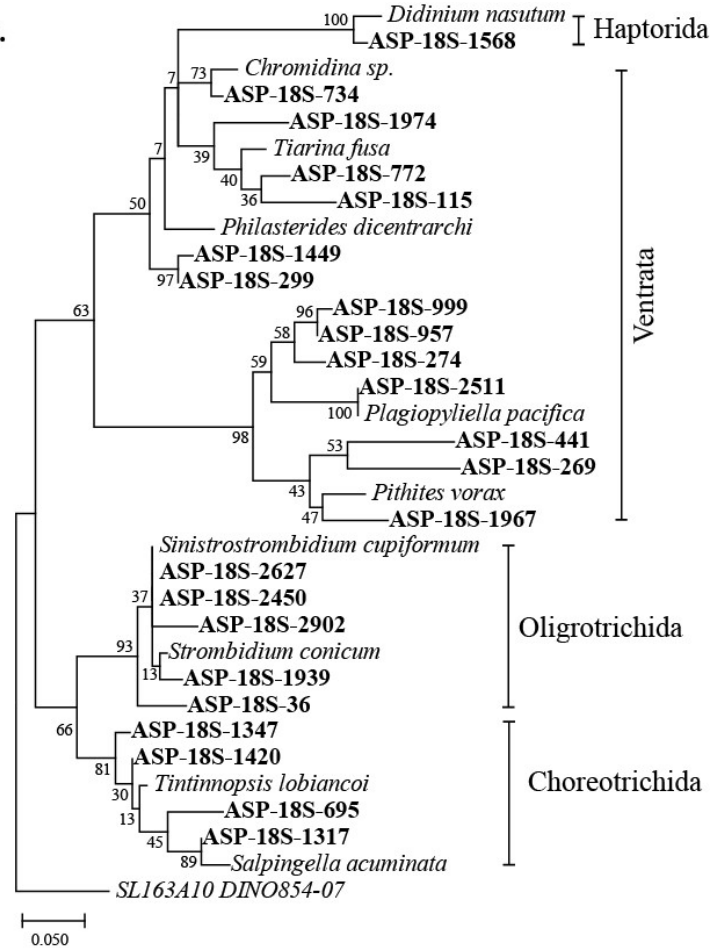

Figure 5: Maximum likelihood tree of the operational taxonomic units (OTU) closely related to dinoflagellates (A) and ciliates (B). Only OTUs representing more than $0.1 \%$ of the total relative abundance of ciliates and dinoflagellates 18S RNA gene reads are included. Reference sequences are indicated in italics. Sea ice OTUs come from a study of protists in the ASP sea ice during the same sampling time (Torstensson et al. 2015). Bootstrap values $(\mathrm{n}=1000)$ are indicated at nodes; scale bar represents changes per positions. 

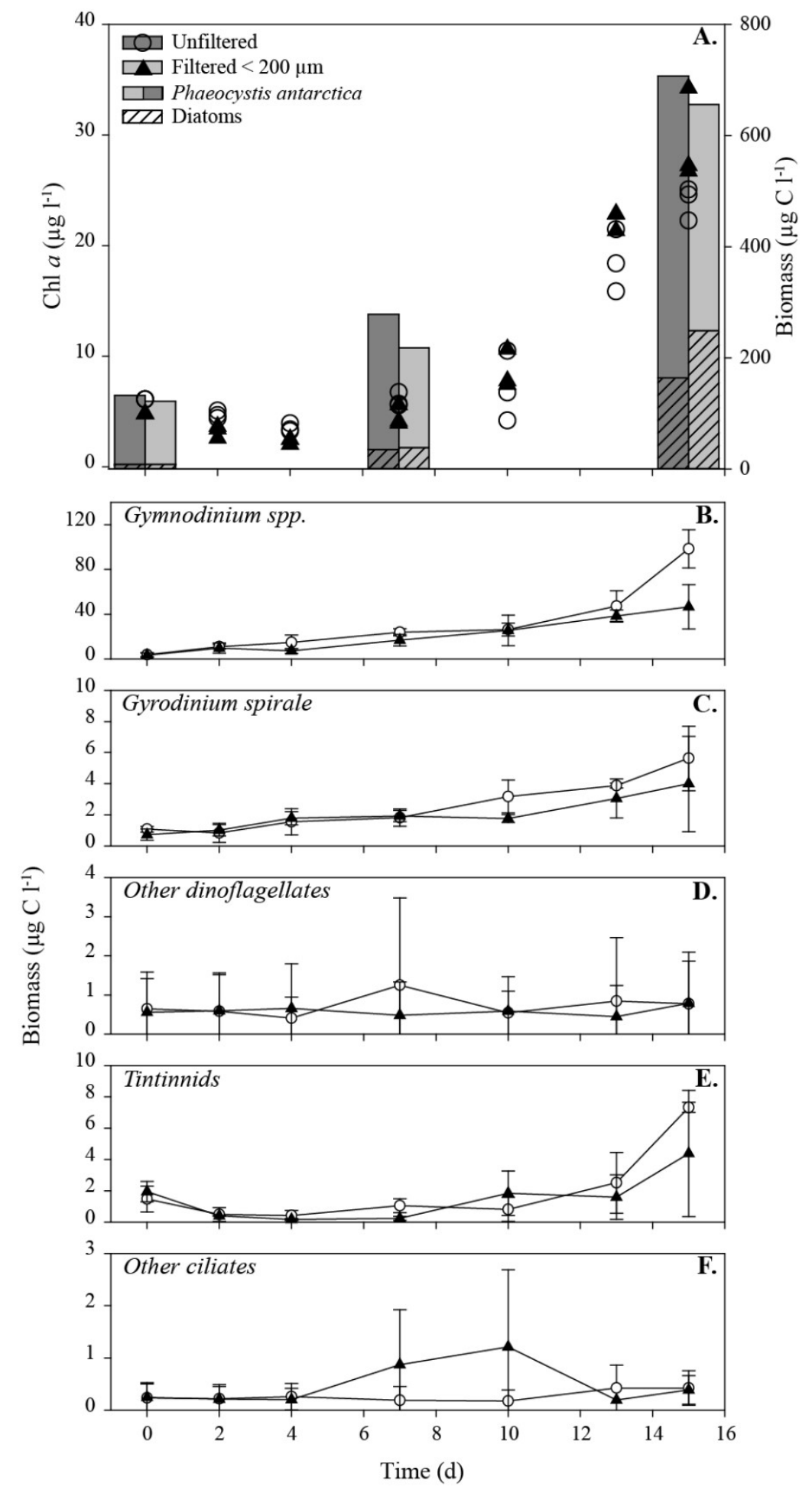

Figure 6: Chlorophyll $a$ concentration and biomass of dominant phytoplankton (A). Biomass of the dominant dinoflagellates (Gymnodinium spp. B., Gyrodinium spirale C. and others D.) and ciliates (Tintinnids E. and others F.) over the course of the induced Phaeocystis antarctica bloom. Mean \pm SD for 3 replicates for each treatment. 